\title{
A Literature Review on Supply Chain Contracts Selection and Coordination under Competing Multi Manufacturers
}

\author{
Xu Liu ${ }^{1,2}$, Qi Xu ${ }^{1}, \&$ Li-Xia Xu ${ }^{1,3}$ \\ ${ }^{1}$ Glorious Sun School of Business and Management, Donghua University, China \\ ${ }^{2}$ School of distance education, Ningxia University, China \\ ${ }^{3}$ Department of Academic Affairs, Ningxia University, China \\ Correspondence: Xu Liu, Glorious Sun School of Business and Management, Donghua University, Shanghai \\ 200051, China. E-mail: xuliu_114@163.com
}

Received: May 5, 2015

Accepted: May 26, 2015

Online Published: June 20, 2015

doi:10.5539/ijbm.v10n7p196

URL: http://dx.doi.org/10.5539/ijbm.v10n7p196

\begin{abstract}
The paper based on the supply chain which under competing multi manufacturers as the research object, reviews the research of supply chain contracts selection and coordination. By reviewing the relevant, summarizes the various methods of supply chain competition, supply chain contracts and supply chain coordination. The results have guiding significance for supply chain coordination under competing multi manufacturers and improvement of supply chains performance. The paper also researches the direction of future development in this domain. The future of multiple manufacturers under the competition of supply chain contract selection and coordination problems research will further according to the practical problems, using the game theory, optimization theory, the theory of system simulation method, building a decision model and method system, to promote the development of the theory of supply chain management, and to guide the practice of supply chain management has important practical value.
\end{abstract}

Keywords: competing multi manufacturers, supply chain contracts, supply chain coordination, review

\section{Introduction}

In the 21st century, supply chain management has already presented globalization, agility, greening and electronization under the tide of the network communication technology, dynamic alliance and technological revolution. Enterprise competition has become the competition between supply chains. Economic globalization makes the supply chain structure becomes more and more complexity, the supply chain management has been put forward higher requirements. Compared with the previous management methods mainly focus on the optimization of internal resources of enterprise, supply chain management more emphasis on coordination and optimization problem between the products related to multiple enterprises.

Most of the manufacturing supply chain products are short life cycle products, they have a relatively short and fixed time for sales, retailers need to order before the sales season. Because retailers are difficult to forecast information of market demand, weighed in on out of stock or inventory backlog is brought profit losses and gains, the retailer through demand forecasting product formulation of the optimal ordering strategy. Because the order quantity retailers unilateral decision is usually to its expected profit optimal decision, it is very difficult to realize the whole supply chain and individual enterprises to achieve the optimal profit at the same time, there is an urgent need to develop effective contract mechanism to promote cooperation and coordination among supply chain members.

At present, the studies of supply chain contract, based on the research of the supply chain structure can be divided into four categories: one manufacturer and one retailer (One-One structure), one manufacturer and more retailers (One More) structure, more manufacturers and one retailer (More-One structure), more manufacturers and more retailers (More and More structures). The first two categories research achievements are very rich, but the research results about after two are relatively small, especially the more manufacturers to more retailers structure is rarely study. But many manufacturers especially many manufacturers under the competition of supply chain coordination and a single manufacturer the situation is entirely different, contract option are also changed. In actual manufacturing, widespread pattern is about multi manufacturers' competition. For example, 
Dell and Intel work hand in hand with their products to the market, but there is also competition between them, this is because they want to make the customers to buy their own brand of computers. Again, for example, in the commodity industry, Colgate company not only supply their products to Carrefour but also to Wal-Mart, and Crest also supply to Carrefour and Wal-Mart, which means fierce competition exists between Colgate and Crest. Therefore, study on supply chain contracts selection and coordination under competing multi manufacturers is very important.

In this article, we take supply chain under competing multi manufacturers as research object and review the research of supply chain contracts selection and coordination. In multi manufacturers competition environment, manufacturers and retailers how to choose contracts to achieve their respective maximum profit while making the supply chain system achieve coordination. The results have guiding significance for supply chain coordination under competing multi manufacturers and improvement of supply chains performance.

In recent decades, the research about supply chain and supply chain management has received wide attention from scholars. At the same time, supply chain management has achieved much fruit by theory research and practice, which is closely related to this article's literature research mainly includes: (1) supply chain competition research; (2) supply chain contract research; (3) supply chain coordination research. Figure 1 shows this article's organization and structure.

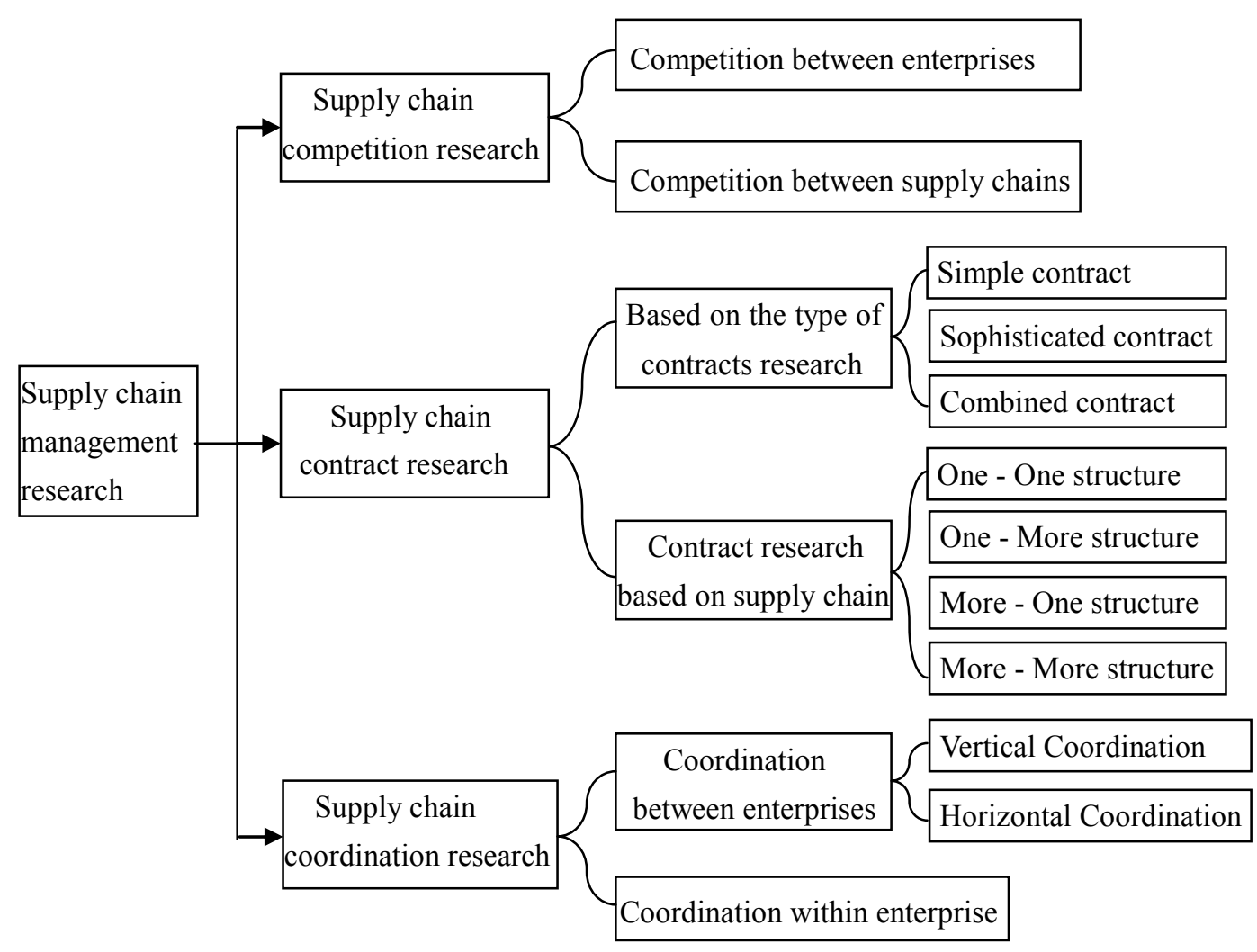

Figure 1. Article's organization and structure

\section{Research on Supply Chain Competition}

Supply chain competition can be divided into competition between enterprises and competition between supply chains. The following research of competition in supply chain from the two competitions described.

\subsection{Competition between Enterprises}

At present, domestic and overseas experts, scholars and enterprises have made great efforts on the research of the competition between enterprises, and many research results were published. To sum up, the existing research mainly focus on two different aspects of price and non-price. The early study of the competition between enterprises mainly with price as the theme, discussed the two products which are under linear demand or 
nonlinear demand price competition. There are lots of representative literatures. Gilbert et al. (2006) assumed that the manufacturer and the supplier both have the opportunity to save cost. They analyzed two competitive manufacturers outsourcing strategy and studied on longitudinal control channels for the supply chain competition led to the manufacturer's choice strategy. Gupta (2008) studied two echelon supply chain consisting of two manufacturers and one common retailer, duopoly game model in Bertrand of linear demand and nonlinear demand under the two level supply chain are given.

With the development of global market competition situation, the market has changed from the traditional seller's market to a buyer's market, people gradually began to realize that only consider the price competition can't adapt to the rapid development of the society. Therefore, researchers began to turn their attention to non-price. At present, research on non-price mainly based on the quality competition, value-added service competition, time competition, inventory level competition, etc. Dumrongsiri et al. (2008) established a supply chain model of direct sales channels there are differences in price and service and traditional retail channels. They analyzed the factors of channel structure, marginal cost, demand changes impact on the market equilibrium, realized double channel sales are better than single traditional retail channel sales. Xu and Cai (2008) considered the competition between perishable products price and delivery date. Hopp and Xu (2008) use of fluid network model to approximate the demand substitution effect, on the basis of uncertain demand inventory competition environment problem among multiple retailers. Yan and Pei (2009) studied the manufacturers introduce direct sales network channel effect on the original traditional retail channels, the introduction of new direct selling channel can stimulate the retailer to improve their service.

\subsection{Competition between Supply Chains}

The above-mentioned only discussed the single internal supply chain participants in horizontal or vertical competitions. But with the development of global economic integration, the competition between enterprises has become the competition between supply chains.

Zhou and Ai (2005) showed that the difference between cost and product has an important effect on the selection of channel structure in the competition between supply chains. Wu et al. (2009) considered joint pricing and quantity decisions and competition under three possible supply chain strategies: Vertical Integration (VI), Manufacturer's Stackelberg (MS), and Bargaining on the Wholesale price $(\mathrm{BW}(\alpha), \alpha$ is the bargaining parameter) over a single or infinitely many periods. They showed that, in contrast to earlier literature, using VIVI (VI in both chains) is the unique Nash Equilibrium over one period decision, while using MSMS or BW $(\alpha) \operatorname{BW}(\alpha)$ may be Nash Equilibrium over infinitely many periods. Cachon and Koek (2010) concluded that the properties a contractual form exhibits in a one-manufacturer supply chain may not carry over to the realistic setting in which multiple manufacturers must compete to sell their goods through the same retailer.

\section{Research on Supply Chain Contract}

Most of the literatures on supply chain contract are established on the research of Pasternack (1985). In the decentralized decision-making supply chain, if the downstream retailer faces the newsvendor problem, the retailer will be according to the manufacturer's wholesale price to choice inventory levels, and the inventory level will be lower than the optimal inventory level in the centralized decision. This study reflects the observed by Spengler (1950) about the double marginalization. Such disorders can be solve by supply chain contracts which were mentioned in Cachon and Lariviere (2005), they are two-part tariff, buyback contract, quantity discount contract, revenue sharing contract, etc.

\subsection{Based on the Type of Contracts Research}

In the process of actual operation, according to different objects and market environment, there are many kinds of contracts. This section is only a summary of some common forms of supply chain contract, mainly divided into simple contract, sophisticated contract and combined contract.

\subsubsection{Simple Contract}

Wholesale price contract is the simplest form of contracts and also is a kind of practice very common contract. It performs difficulty is small, the cost is low, all market risk borne by retailers, manufacturers make riskless profits, therefore preference by suppliers. But the contract cannot make the supply chain coordination. Lariviere and Porteus (2001) considered a simple supply-chain contract in which a manufacturer sells to a retailer facing a newsvendor problem and the lone contract parameter is a wholesale price. They explored factors that may lead the manufacturer to set a wholesale price below that which would maximize her profit, concentrating on retailer participation in forecasting and retailer power. Dong and Rudi (2004) studied two kinds of wholesale price 
contract, that is, the wholesale price is determined by external or internal supply chain. When the stock transfer profit distribution, the manufacturers get larger profit and the retailers get smaller profit.

\subsubsection{Sophisticated Contract}

\section{A. Buyback Contract}

Buyback contract refers to the manufacturer buy back the products which are not sold by retailers less than wholesale prices, so the transfer of profits of the contract is on the basis of the profits to pay the wholesale price contract, excluding those did not sell products buyback value. Buyback contract is a widely used contract, mainly aimed at the demand uncertainty, the market of short life cycle products. Zhang and Tang (2012) studied the influence of capital earning on supply chain contracts by discussing buyback contracts. They found that the buyback price may be more than the wholesale price, and the wholesale price may be less than the marginal cost of the manufacturer when the capital earning is considered. Wu et al. (2013) setup a supply chain model based on a buyback contract by drawing into deviation cost. They showed that the origin production plan and the buy back price of the manufacturer had a robustness zone when stochastic market demand distribution function and production cost fluctuated simultaneously to a small extent as for the close-loop supply chain under asymmetric information, it is the optimal decision for the manufacturer to keep the original production plan and the original buyback contract in the zone. Lin and Hou (2014) established the extended utility function including the preference of reciprocity based on the model of buyback contract.

\section{B. Revenue Sharing Contract}

Revenue sharing contract was first used in the video rental industry, later extended to other industries. Revenue sharing contract, the retailer for manufacturers share some of its earnings, in return for their wholesale price discount. Dana and Spier (2001) analyzed revenue sharing contract under the perfect competition of retail market. Wang et al. (2004)considered the external demand related with price, the revenue sharing contract is discussed, and the different assumptions on two kinds of demand price have carried on the contrastive analysis. But the revenue sharing contract are used such a premise: supply chain revenue from all the retailers, the supply chain revenue is observed for members, researched by Krishnan et al. (2004). Cachon and Lariviere (2005) proposed in general revenue sharing contract analysis framework.

\section{Quantity Discount Contract}

Quantity discount contract is a kind of price concessions from enterprises given to the customers who purchase of a large number of products. Generally speaking, the more buy, the more discount. Encouraging customers to increase the purchases, or to buy from the same company, or purchase in advance. Under the price-elastic demand,Weng (1995) established a more homogeneous the buyer all the incremental price discount model, and through the model to deduce the price discount and incremental price discount in the channel coordination relations. Relative to the previous literature by considering the cost of the added value of perfect, this price discount rate is just for an interval, and no specific determine the discount rate. Bernstein and Federgruen (2005) proved that one manufacturer and more retailers, on the demand uncertainty (random distribution function), retail prices are endogenous, buyback contract can not make supply chain coordination. Pointed out that quantity discount contract is easy to perform and observe than revenue sharing contract.

\section{Transfer-Payment Contract}

For the supply chain system, the majority of literatures mainly about the optimal inventory replenishment strategy under centralized control, a few scholars studied the coordination of the multi echelon inventory system under decentralized control. Federgruen and Zipkin (1984) found by properly tectonic transfer payment function, under the decentralized control, the multilevel inventory system can achieve maximum efficiency of the centralized control solution. Lee and Wang (1999) and Chen et al. (2001) respectively, according to this idea, based on supply chain performance indicators that can be observed. For example, inventory levels, out of stock transfer function is constructed, which change the cost of each entity in the supply chain structure, make under decentralized control supply chain to achieve optimal efficiency, achieve the goal of the collaboration.

\section{E. Two-Part Tariff}

In two-part tariff, manufacturers charge equal to the marginal cost of the wholesale price, at the same time for a share of the royalties. Two-part tariff is often used to analysis monopoly behavior and welfare results, or to prove that this pricing mode is equal to price discrimination. Lafontaine (1992) through empirical research on the application of royalty. Ni et al. (2004) based on the recognition of defects in the literatures on two-part tariff, modeled retailer's long-run ration, derived the monopolistic pricing equilibrium, and studied the features in the equilibrium. Li and Zhao (2014) showed that when only the manufacturer has fairness preference, two-part tariff 
can coordinate supply chain; when both the manufacturer and the retailer have preference, in acrimonious channel under constraints of certain parameters, two-part tariff cannot coordinate the supply chain.

\subsubsection{Combined Contract}

Many times, the independent form of a contract cannot coordinate the supply chain truly, need more than two contracts are combined. At present, many scholars have made a deep research about combined contract. Zhao and Xie (2008) present a model to analyze the combined contract of supply chain with wholesale price and price protection for short-life-cycle product, in which the retailer has only one ordering chance and selling their products with different marketing price in different selling periods. Wang et al. (2009) research on a combined contract with the buyback and quantity discount to solve the problem that only the buyback contract or quantity discount contract cannot coordinate the supply chain is developed. Xu Qi (2011) investigated the model of combined contract by the analysis partier's expected profits of three scenarios. The first is whole sale contracts. The second is under the adoption of buyback contract. The third is under the adoption of combined contract of buyback and pricing flexible. She illustrated the benefit of the combined contract to the coordination of supply chain and flexible the arrangement of profits between manufacturers and retailers. Zeng and Luo (2014) investigated inventory control and coordination issues in a decentralized supply chain with combined contracts of price discount and trade-credit.

\subsection{Contract Research Based on Supply Chain Structure}

\subsubsection{One Manufacturer and One Retailer (One-One structure)}

Research on supply chain contracts are mostly around the structure of one manufacturer and one retailer. Caldentey and Haugh (2009) took One-One structure as research object, through introduction of financial hedging, compared the two different flexible contracts. Studies have shown that manufacturer prefer to flexible contract with hedging. Pan et al. (2010) studied one manufacturer and one retailer structure of revenue sharing contract and wholesale price contract, proved that the revenue sharing contract can not only realize the Pareto optimality, but also can achieve arbitrary allocation of supply chain benefits.

\subsubsection{One Manufacturer and More Retailers (One-More Structure)}

Liu (2007) showed that one-more structure can be coordinated by selecting a proper reward and punishment factor and the least sales scale being restricted within a certain interval. Under this contract system, the efficiency of decentralized supply chain equals that of integrated supply chain. Xu and Zhu (2009) studied a two-level supply chain, consisting of one manufacturer and two retailers, where the manufacturer presets the wholesale prices and location restrictions, then two retailers competes in a two-stage dynamic game. They showed that the contract can simultaneously inspirit the retailers to reduce cost. Zhou and Wang (2011) explored the cooperative advertising problem by considering the situation where a manufacturer sells its product through two competing retailers facing Newsvendor problem. The effect of brand name investment and local advertising expenditures on each retailer's demand, and the influence of competition between the retailers on each member's optimal advertising policy are analyzed.

\subsubsection{More Manufacturers and One Retailer (More-One Structure)}

Some other scholars studied the supply chain system with multiple manufacturers and one retailer. Wang (2006) studied the multiple manufacturers and one retailer of two echelon supply chain in the revenue sharing contract. They assumed that the manufacturers' decision variables include the retail price and inventory, and the contract model has been optimized. Cachon and Koek (2010) studied with two manufacturers and one retailer structure, discussed the manufacturers' contract choice problem. They found that, in the structure of two manufacturers and one retailer, relative to the wholesale price contract, senior contract instead, jeopardizing the interests of manufacturers.

\subsubsection{More Manufacturers and More Retailers (More-More Structure)}

A few scholars studied the more manufacturers and more retailers situation. Perakis and Roels (2007) quantified the efficiency of decentralized supply chains that use price-only contracts. They measured efficiency with the price of anarchy (PoA), defined as the largest ratio of profits between the integrated supply chain (that is, fully coordinated) and the decentralized supply chain. They characterized the efficiency of various supply chain configurations: push or pull inventory positioning, two or more stages, serial or assembly systems, single or multiple competing suppliers, and single or multiple competing retailers. 


\section{Research on Supply Chain Coordination}

Supply chain coordination originated in the system dynamics, specifically refers to demand information delay, amplification and oscillation, the existence of dynamic phenomenon reduced the effectiveness of the system operation. Malone and Crowston (1994) defined coordinate is the process of independence between management activities. The purpose of the coordinate system is hope through some methods to control the system and transfer it from disorderly to orderly, enable the system to achieve synergy. The higher system synergy, the greater output effects. The negative effect of the system will become smaller, the result is more valuable. Generally speaking, the need for coordination of system often contains several contradictory and conflict subsystem or contains different evaluation standard of the participants for each goal. For these systems, if cannot be properly handle the conflicts through coordination or negotiation to reach a compromise, the system's overall function to the instability of the system structure of macro and no results, even produce negative effects, namely the various parts of the system's overall function is less than the molecular system function combined.

Later, academia and industry, it is known as the "bullwhip effect". Lee et al. (2004) regarded this phenomenon as a kind of information distortion problem, and a detailed analysis of the source of bullwhip effect produced. Bullwhip effect was not been focused until the early 1990s, and then have been successfully applied to the operation of enterprises. Coordination is a key concept in the modern supply chain management, the concept of the supply chain itself contains the including multiple independent decision makers, and the decision makers are often scattered under the condition of independent decision making, so the final result for the whole supply chain are rarely optimal. Only when these decision makers act to achieve some degree of coordination is likely to make the whole supply chain optimization. Reference to other areas of coordination concept, and considering the characteristics inherent in supply chain, many scholars put forward the definition of supply chain coordination. Sahin and Robinson (2002) defined supply chain coordination is the decision-making behaviors of all the members are all in order to achieve system global state. Researchers at Cachon and Lariviere (2005) think if the optimal decision-making of supply chain system constitute a Nash equilibrium of each trading members, there is no members intend to deviate from the balanced, so as to achieve supply chain coordination. Other scholars include Seungjin (1995), Pasternack (2008) have similar definition.

At present, the research on supply chain coordination with plenty of fruits, the following two categories are reviewed.

\subsection{Coordination between Enterprises}

According to the enterprises' position in the supply chain, the coordination between enterprises can be divided into Vertical Coordination and Horizontal Coordination.

\subsubsection{Vertical Coordination}

Vertical coordination is refers to the process throughout the product life of the coordination between the relevant enterprises (upstream and downstream enterprises), that is to say, from raw materials procurement to production, the sale until the customer coordination between suppliers, manufacturers and retailers. Cattani et al. (2006) studied coordination problems between different enterprises, in the two layers of a manufacturer and a retailer in the supply chain system, manufacturers to increase the network direct marketing channels after two sales channel pricing problem. In this model, they considered the convenience of the channels of the factors (i.e., consumers to buy the required effort level), the results found that when the Internet channel is considered to be inconvenient, manufacturers are more inclined to two channels the same pricing strategy. Kurata et al. (2007) studied in the supply chain of the national brand and local brand competition, using demand function formal parameter, through the price elasticity parameters reflect the customer's choice of brands, stores, the Nash equilibrium is given. Cai et al. (2009) studied the influence of price discount for supply chain coordination, under uniform prices and non-uniform prices. They argued that the uniform price and the price discount can alleviate the channel conflict, improving supply chain performance. Hua et al. (2010) studied the supply chain under the centralized decision-making and decentralized decision-making, using two phase optimization method and Stackelber game model to analyze the manufacturer and the retailer's optimal delivery time and optimal price. Jain et al. (2011) explored the competitive environment of the supply chain contract and information sharing mechanism, ensuring the timely and efficient supply chain alliance enterprises can finish the work, finally realized the "win-win". Parlakturk (2012) targeted the key customers, mining product diversity of these customers. Ceryan et al. (2013) aimed at manufacturers who provide a wide range of products of mismatches between supply and demand, price and the number of alternatives is proposed based on coordination mechanism. Liu and Zhang (2013) classified products, in view of the strategic its pricing mechanism is explored for the key customers. 


\subsubsection{Horizontal Coordination}

Horizontal coordination refers to the enterprises in the same position in the supply chain coordination, such as various retailers' coordination. When the manufacturer's inventory can't meet the needs of retailers, the supply chain system can carry out inventory coordination between different retailers. Balasubramanian (1998) studied horizontal coordination among the enterprises, analyzed the market coverage of the impact of channel structure equilibrium. Yao et al. (2009) studied from the perspective of manufacturers' control the supply chain, respectively to study the centralized strategy, stackelberg strategies and outsourcing electronic channels strategy, analyzed the best inventory level and the expected profit of each strategy. Chiang (2010) found that although revenue sharing contract mechanism can improve system performance, but short of coordinate system. They designed a combination mechanism of shared inventory holding costs and direct channel revenue to achieve coordination. Takahashi et al. (2011) found that production and delivery arrangement inventory strategy can without any increase in inventory at the same time effectively reduce the production and delivery times, it is very effective for the operation of short life cycle products. Comez et al. (2012) researched with multiple rival retailers' transport problems, the specific constraints is obtained under the condition of the optimal transfer capacity and its supplementary measures.

\subsection{Coordination within Enterprise}

Serifert et al. (2004) put forward and solved by a forward contract to purchase the optimal order quantity and purchasing through the spot market, the mathematical model of the optimal order quantity, and from the perspective of the supply chain has carried on the quantitative analysis to the benefits of using the spot market. Boyaei (2005) studied the competition of supply chain inventory and coordination in Nash game situation. They designed buyback and the combination of rewards and punishments contract mechanism to realize the coordination of supply chain. Kumar and Venkatesan (2005) found with nonlinear relation between returns and multi-channel shopping, established the corresponding indicators to measure the benefits of multi-channel shopping. Devaraj et al. (2006) studied behavior and impact of economic factors on online consumer satisfaction, and then the contribution to the online channel preference was given. Geng and Mallik (2007) studied supply chain coordination of double channel capacity constraints, under retailers were host countermeasures in stackelberg game. Reverse revenue sharing and transfer-payment combined contract is established to implement supply chain coordination of double channel. Albesa (2007) through an empirical study of the financial sector analyzes the influence factors of consumer channel choice behavior, including perceived convenience, social relations, channel knowledge and privacy. Bo-chiuan (2008) depict the consumer online search behavior, found that when the search cost reduction, price information search and product search will increase, but the store search did not change significantly. Forman et al. (2009) had carried on the empirical analysis by using Amazon.com, illustrated the importance of the transportation cost of buying online, and proved that the transport cost or travel cost really seriously affect consumers' purchase decision. Chen and Bell (2012) introduced return mechanism into buyback contract, by building a model analysis of full return and no-full return of the two kinds of situations of their respective optimal ordering strategy. Vairaktarakis (2013) studied non-cooperative mode between manufacturers of subcontracting strategy, illuminated non-cooperative model easy to produce the double marginal effect, non-cooperative game model was constructed and subcontract strategies of the non-cooperative model were obtained.

From the above research can find that although the research of supply chain contracts selection and coordination have begun, but most structures are one manufacturer and one retailer or one manufacturer and more retailers. Research of more manufacturers' structure are very few, especially multiple manufacturers under the competition of supply chain is little research. General contract of supply chain, such as the wholesale price contract, buyback contract and quantity discount contract, etc., under the different supply chain structures have different selective advantage. Therefore, under multiple manufacturers' competitive environment, manufacturers and retailers achieve their maximum profit and how to choose the contract to coordinate supply chain system. They are new problems of node enterprises in supply chain and supply chain management.

\section{Conclusions and Expectations}

To sum up, on the one hand, most of the research is based on a single supply chain as the research object, and research related to supply chain structure is mainly one manufacturer to one retailer and one manufacturer to multiple retailers. On the other hand, expanding single supply chain to multiple supply chains, but the study of multiple manufacturers competition decision model is still in its infancy.

First of all, current studies of supply chain contract, most is about one manufacturer to one retailer or one manufacturer to multiple retailers, less of multiple manufacturers to one retailer and multiple manufacturers to 
multiple retailers, especially more manufacturers under the competition of supply chain contract research are much rarer. Supply chain contract is state dependent, that depends on the supply chain environment, and more manufacturers competition environment, supply chain members should be how to choose the trade contract is completely different from one manufacturer of supply chain contract choice, namely manufacturers competition strength to choose the impact of supply chain contract.

Secondly, some research while considering the competition among supply chain members, but most of the existing achievements is a single supply chain (e.g., one manufacturer and one retailer, one manufacturer and more retailers, more manufacturers and one retailer), less consider multiple (that is, more manufacturers and more retailers) under the competition of supply chain supply chain contract selection and coordination problems. In reality, a past solo competition between the enterprise and enterprise mode gradually transformed into competition between supply chain and supply chain pattern, the more manufacturers in different supply chain competition environment, supply chain members how to choose the suitable contract to achieve supply chain coordination has become the focus of theoretical research and business management.

Thirdly, Related research mostly focused on the analysis of the intensity of competition between supply chains influence on each vertical structure of supply chain decisions, the analysis of the supply chain and supply chain competition environment, each of the supply chain is to choose the centralized decision-making and decentralized decision making, and studies the basic assumption of two supply chains status is equal and with asymmetric information, which is related to the conclusion is based on the two manufacturers under the symmetric information static game. On the one hand, these studies ignored the status ranging between supply chains. On the other hand, ignoring the asymmetric information between supply chain game. In real life, dynamic game phenomenon between the supply chains is objective existence. For example, in the clothing, mobile phones, automotive and other industries, are often one brand price first, the other brands competition according to the observed price to make the optimal response. And, there is a benefit conflict between the supply chains, will not enjoy each other "secret" information, such as production cost information, demand information, etc., that is to say, competition between the supply chains' information are often asymmetry, but the existing literatures are less consider these situations.

Finally, the existing studies are mostly assumed that the two supply chains without overlapping nodes, less consider the overlap between supply chains nodes. But in reality between supply chain and supply chain is not completely independent, frequently overlapping nodes. For example, in the commodity industry, Colgate company not only supply to Carrefour, but also supply to Wal-Mart, and Crest also supply to Carrefour and Wal-Mart, that is to say, Colgate and its retailers have overlap retail nodes with Crest and its retailers.

In conclusion, the future of multiple manufacturers under the competition of supply chain contract selection and coordination problems research will further according to the practical problems, using the game theory, optimization theory, the theory of system simulation method, building a decision model and method system, to promote the development of the theory of supply chain management, and to guide the practice of supply chain management has important practical value.

\section{Acknowledgments}

The authors thank the editor, associate editor, and two reviewers for their constructive comments, which have improved this article tremendously. This work is partly supported by the National Natural Science Foundation of China (NSFC, project no.:71172174), Shanghai Pujiang Program (project no.:12PJC020), Innovation Program of Shanghai Municipal Education Commission (project no.:12ZS58), Shanghai Philosophy and Social Science Planning Program (project no.:2013BGL014), Natural Science Foundation of Ningxia University (project no.: NDZR1341).

\section{References}

Albesa, J. G. (2007). Interaction channel choice in a multichannel environment, an empirical study. International Journal of Bank Marketing, 25(7), 490-506. http://dx.doi.org/10.1108/02652320710832630

Balasubramanian, S. (1998). Mail versus mall: A strategic analysis of competition between direct marketers and conventional retailers. Marketing Science, 17(3), 181-195. http://dx.doi.org/10.1287/mksc.17.3.181

Bernstein, F., \& Federgruen, A. (2005). Decentralized supply chains with competing retailers under demand uncertainty. Management Science, 51(1), 18-29. http://dx.doi.org/10.2307/20110304

Bo-chiuan, S. (2008). Characteristics of Consumer Search On-Line: How Much Do We Search?. International Journal of Electronic Commerce, 13(1), 109-129. http://dx.doi.org/10.2753/JEC1086-4415130104 
Boyaei, T. (2005). Competitive stoking and coordination in a multi-channel distribution system. IIE Transactions, 37(5), 407-427. http://dx.doi.org/10.1016/j.ejor.2006.08.041

Cachon, G. P., \& Koek, A. G. (2010). Competing Manufacturers in a Retail Supply Chain: On Contractual Form and Coordination. Management Science, 56(3), 571-589. http://dx.doi.org/10.1287/mnsc. 1090.1122

Cachon, G. P., \& Lariviere, M. A. (2005). Supply chain coordination with revenue-sharing contracts: Strengths and limitations. Management Science, 51(1), 30-44. http://dx.doi.org/10.2307/20110305

Cai, G., Zhang, Z. G., \& Zhang, M. (2009). Game theoretical perspectives on dual-channel supply chain competition with price discounts and pricing schemes. International Journal of Production Economics, 117(1), 80-96. http://dx.doi.org/10.1016/j.ijpe.2008.08.053

Caldentey, R., \& Haugh, M. B. (2009). Supply Contracts with Financial Hedging. Operations Research, 57(1), 47-65. http://dx.doi.org/10.2307/25614730

Cattani, K., Gilland, W., Heese, H. S., \& Swaminathan, J. (2006). Boiling frogs: Pricing strategies for a manufacturer adding a direct channel that competes with the traditional channel. Production and Operations Management, 15(1), 40-56. http://dx.doi.org/10.1002/esp.1558

Ceryan, O., Sahin, O., \& Duenyas, I. (2013). Dynamic Pricing of Substitutable Products in the Presence of Capacity Flexibility. M\&Som-Manufacturing \& Service Operations Management, 15(1), 86-101. http://dx.doi.org/10.1287/msom.1120.0404

Chen, F. R., Federgruen, A., \& Zheng, Y. S. (2001). Coordination mechanisms for a distribution system with one supplier and multiple retailers. Management Science, 47(5), 693-708. http://dx.doi.org/10.1287/mnsc.47.5.693.10484

Chen, J., \& Bell, P. C. (2012). Implementing market segmentation using full-refund and no-refund customer returns policies in a dual-channel supply chain structure. International Journal of Production Economics, 136(1), 56-66. http://dx.doi.org/10.1016/j.ijpe.2011.09.009

Chiang, W. Y. K. (2010). Product availability in competitive and cooperative dual-channel distribution with stock-out based substitution. European Journal of Operational Research, 200(1), 111-126. http://dx.doi.org/10.1016/j.ejor.2008.12.021

Comez, N., Stecke, K. E., \& Cakanyildirim, M. (2012). In-Season Transshipments Among Competitive Retailers. M\&Som-Manufacturing \& Service Operations Management, 14(2), 290-300. http://dx.doi.org/10.1287/msom.1110.0364

Dana, J. D., \& Spier, K. E. (2001). Revenue sharing and vertical control in the video rental industry. Journal of Industrial Economics, 49(3), 223-245. http://dx.doi.org/10.1111/1467-6451.00147

Devaraj, S., Fan, M., \& Kohli, R. (2006). Examination of online channel preference: Using the structure-conduct-outcome framework. Decision Support Systems, 42(2), 1089-1103. http://dx.doi.org/10.1016/j.dss.2005.09.004

Dong, L. X. R. N. (2004). Who benefits from transshipment? exogenous vs. endogenous wholesale prices. Management Science, 50(5), 645-657. http://dx.doi.org/10.1287/mnsc.1040.0203

Dumrongsiri, A., Fan, M., Jain, A., \& Moinzadeh, K. (2008). A supply chain model with direct and retail channels. European Journal of Operational Research, 187(3), 691-718. http://dx.doi.org/10.1016/j.ejor.2006.05.044

Federgruen A, Z. P. (1984). Computational issues in an infinite-horizon, multiechelon inventory model. Operations Research, 32(4), 818-836. http://dx.doi.org/10.1287/opre.32.4.818

Forman, C., Ghose, A., \& Goldfarb, A. (2009). Competition Between Local and Electronic Markets: How the Benefit of Buying Online Depends on Where You Live. Management Science, 55(1), 47-57. http://dx.doi.org/10.2307/40539126

Geng, Q., \& Mallik, S. (2007). Inventory competition and allocation in a multi-channel distribution system. European Journal of Operational Research, 182(2), 704-729. http://dx.doi.org/10.1016/j.ejor.2006.08.041

Gilbert, S. M., Xia, Y., \& Yu, G. (2006). Strategic outsourcing for competing OEMs that face cost reduction opportunities. Iie Transactions, 38(11), 903-915. http://dx.doi.org/10.1080/07408170600854644.

Gupta, S. (2008). Channel structure with knowledge spillovers. Marketing Science, 27(2), 247-261. http://dx.doi.org/10.2307/40057100 
Hopp, W. J., \& Xu, X. (2008). A static approximation for dynamic demand substitution with applications in a competitive market. Operations Research, 56(3), 630-645. http://dx.doi.org/10.2307/25147217

Hua, G. W., Wang, S. Y., \& Cheng, T. C. E. (2010). Price and lead time decisions in dual-channel supply chains. European Journal of Operational Research, 205(1), 113-126. http://dx.doi.org/10.1016/j.ejor.2009.12.012

Jain, A., Seshadri, S., \& Sohoni, M. (2011). Differential Pricing for Information Sharing Under Competition. $\begin{array}{llll}\text { Production and } \quad \text { Operations 20(2), } & \text { 235-252. }\end{array}$ http://dx.doi.org/10.1111/j.1937-5956.2010.01161.x

Krishnan, H., Kapuscinski, R., \& Butz, D. A. (2004). Coordinating contracts for decentralized supply chains with retailer promotional effort. Management Science, 50(1), 48-63. http://dx.doi.org/10.1287/mnsc.1030.0154

Kumar, V., \& Venkatesan, R. (2005). Who are the multichannel shoppers and how do they perform?: Correlates of multichannel shopping behavior. Journal of Interactive Marketing, 19(2), 44-62. http://dx.doi.org/10.1002/dir.20034

Kurata, H., Yao, D. Q., \& Liu, J. J. (2007). Pricing policies under direct vs. indirect channel competition and national vs. store brand competition. European Journal of Operational Research, 180(1), 262-281. http://dx.doi.org/10.1016/j.ejor.2006.04.002

Lafontaine, F. (1992). Agency theory and franchising: Some empirical results. Rand Journal of Economics, 23(2), 263-283. http://dx.doi.org/10.1080/10580530.1992.716997

Lariviere, M. A. P. E. L. (2001). Selling to the newsvendor: An Analysis of Price-only contracts. Manufacturing \& Service Operations Management, 3(4), 293-305. http://dx.doi.org/10.1287/msom.3.4.293.9971

Lee, H., \& Whang, S. J. (1999). Decentralized multi-echelon supply chains: Incentives and information. Management Science, 45(5), 633-640. http://dx.doi.org/10.1287/mnsc.45.5.633

Lee, H. L., Padmanabhan, V., \& Whang, S. (2004). Information distortion in a supply chain: the bullwhip effect. Management Science, 50(12), 1875-1886. http://dx.doi.org/10.1287/mnsc.1040.0266

Li, Y., \& Zhao, D. Z. (2014). Low-carbonization Supply Chain Two-part Tariff Coordination Based on Fairness Preference. Management Review, (01), 159-167. http://dx.doi.org/10.14120/j.cnki.cn11-5057/f.2014.01.010

Lin, R. H., \& Hou, R. J. (2014). The Effect of Reciprocity on Buyback Contract Coordination and Decision Behaviors. Industrial Engineering and Management, (01), 85-90. http://dx.doi.org/10.1016/j.ijpe.2014.05.004

Liu, C. L. (2007). Contract coordination of supply chain system based on multi retailers. Journal of Management Sciences in China, (02), 1-6+18. http://dx.doi.org/10.1007/s00170-003-1626-x

Liu, Q., \& Zhang, D. (2013). Dynamic Pricing Competition with Strategic Customers Under Vertical Product Differentiation. Management Science, 59(1), 84-101. http://dx.doi.org/10.1287/mnsc.1120.1564

Malone, T. W., \& Crowston, K. (1994). The interdisciplnary study of coordination. Acm Computing Surveys, 26(1), 87-119. http://dx.doi.org/10.1145/174666.174668

Ni, D. B., Tang, X. W., \& Zeng, Y. (2004). The Two-part Pricing under Consumers' Flexible Behaviors. Systems Engineering-theory \& Practice, (03), 15-20. http://dx.doi.org/10.1002/mde.1510

Pan, K., Lai, K. K., Leung, S. C. H., \& Xiao, D. (2010). Revenue-sharing versus wholesale price mechanisms under different channel power structures. European Journal of Operational Research, 203(2), 532-538. http://dx.doi.org/10.1016/j.ejor.2009.08.010

Parlakturk, A. K. (2012). The Value of Product Variety When Selling to Strategic Consumers. M\&Som-Manufacturing \& Service Operations Management, 14(3), 371-385. http://dx.doi.org/10.1287/msom.1120.0377

Pasternack, B. A. (1985). Optimal pricing and return policies for perishable commodities. Marketing Science, 4(2), 166-176. http://dx.doi.org/10.2307/183789

Pasternack, B. A. (2008). Optimal pricing and return policies for perishable commodities. Marketing Science, 27(1), 133-140. http://dx.doi.org/10.1287/mksc.1070.0347

Perakis, G., \& Roels, G. (2007). The price of anarchy in supply chains: Quantifying the efficiency of price-only contracts. Management Science, 53(8). http://dx.doi.org/1249-1268. 10.1287/mnsc.1060.0656

Sahin, F., \& Robinson, E. P. (2002). Flow coordination and information sharing in supply chains: Review, 
implications, and directions for future research. Decision Sciences, 33(4), 505-536. http://dx.doi.org/10.1111/j.1540-5915.2002.tb01654.x

Seifert, R. W., Thonemann, U. W., \& Hausman, W. H. (2004). Optimal procurement strategies for online spot markets. European Journal of Operational Research, 152(3), 781-799. http://dx.doi.org/10.1109/ICMSS.2004.5302531

Seungjin, W. (1995). Coordination in operations: A taxonomy. Journal of Operations Management, 12(3-4), 413-422. http://dx.doi.org/10.1016/0272-6963(95)00010-P

Spengler, J. J. (1950). Vertical integration and antitrust policy. Journal of Political Economy, 58(4), 347-352. http://dx.doi.org/10.1016/0308-5961(95)00026-3

Takahashi, K., Aoi, T., Hirotani, D., \& Morikawa, K. (2011). Inventory control in a two-echelon dual-channel supply chain with setup of production and delivery. International Journal of Production Economics, 133(1), 403-415. http://dx.doi.org/10.1016/j.ijpe.2010.04.019

Vairaktarakis, G. L. (2013). Noncooperative Games for Subcontracting Operations. M\&Som-Manufacturing \& Service Operations Management, 15(1), 148-158. http://dx.doi.org/10.1287/msom.1120.0410

Wang, D. P., Su, H. X., \& Ouyang, Q. G. (2009). Combined Contract of a Supply Chain with Price-dependent Demands. Chinese Journal of Management, (04), 440-443. http://dx.doi.org/10.1093/imaman/dpm001

Wang, Y. (2006). Joint pricing-production decisions in supply chains of complementary products with uncertain demand. Operations Research, 54(6), 1110-1127. http://dx.doi.org/10.1287/opre.1060.0326

Wang, Y. Z., Jiang, L., \& Shen, Z. J. (2004). Channel performance under consignment contract with revenue sharing. Management Science, 50(1), 34-47. http://dx.doi.org/10.1287/mnsc.1030.0168

Weng, Z. K. (1995). Modeling Quantity Discounts under General Price-Sensitive Demand-Functions-Optimal Policies and Relationships. European Journal of Operational Research, 86(2), 300-314. http://dx.doi.org/10.1016/0377-2217(94)00104-K

Wu, D., Baron, O., \& Berman, O. (2009). Bargaining in competing supply chains with uncertainty. European Journal of Operational Research, 197(2), 548-556. http://dx.doi.org/10.1016/j.ejor.2008.06.032

Wu, Z. H., Chen, H., \& Zhao, Q. (2013). Closed-loop Supply Chain Coordination under Asymmetric Information and Disruptions with Buy Back Contract. Chinese Journal of Management Science, (06), 97-106. http://dx.doi.org/10.1111/j.1937-5956.2012.01124.x

Xu, B., \& Zhou, D. L. (2009). Coordination Strategy Design for Two-level Supply Chain with Retailers' Horizontal Competition. Journal of Industrial Engineering and Engineering Management, (04), 54-58. http://dx.doi.org/1004-6062(2009)23:4<54:LSSSPJ>2.0.TX

Xu, Q. (2011). Jointly Contract of Buy Back and Pricing Flexible for Supply Chain Coordination under Price Changing on Demand. Forecasting, (04), 25-29. http://dx.doi.org/CJFDTOTAL-YUCE201104006

Xu, X., \& Cai, X. (2008). Price and delivery-time competition of perishable products: existence and uniqueness of Nash equilibrium. Journal of Industrial and Management Optimization, 4(4), 843-859. http://dx.doi.org/10.3934/jimo.2008.4.843

Yan, R., \& Pei, Z. (2009). Retail services and firm profit in a dual-channel market. Journal of Retailing \& Consumer Services, 16(4), 306-314. http://dx.doi.org/10.1109/ICMSE.2009.6930243

Yao, D. Q., Yue, X., Mukhopadhyay, S. K., \& Wang, Z. P. (2009). Strategic inventory deployment for retail and e-tail stores. Omega-International Journal of Management Science, 37(3), 646-658. http://dx.doi.org/10.1016/j.omega.2008.04.001

Zeng, S. Q., \& Luo, J. W. (2014). Coordinating Strategies with Combined Contracts of Price Discount and Trade Credit in a Supply Chain. Journal of Industrial Engineering and Engineering Management, (04), 106-111+181. http://dx.doi.org/10.1016/j.ijpe.2014.05.011

Zhang, Y. G., \& Tang, X. W. (2012). The Supply Chain's Buy-back Contract Considering Capital Earning. Journal of Industrial Engineering and Engineering Management, (01), 137-142. http://dx.doi.org/CJFDTOTAL-GLGU201201021

Zhao, Z. J., \& Xie, Q. H. (2008). Combined Contract of Supply Chain with Wholesale Price and Price Protection. Journal of Industrial Engineering and Engineering Management, (04), 163-167. http://dx.doi.org/CJFDTOTAL-GLGU200804032 
Zhou, L., \& Ai, X. Z. (2005). Study about the asymmetry competing channel structure under bargaining power. Journal of Electronic Science and Technology of China, 3(1), 87-90. http://dx.doi.org/10.1590/S0121-47052007000200006

Zhou, Y. W., \& Wang, S. D. (2011). Coordination models of cooperative advertising under stochastic demand in a one-manufacturer two-retailer supply chain system. Journal of Systems Engineering, (02), 203-210. http://dx.doi.org/10.1016/j.ejor.2011.08.010

\section{Copyrights}

Copyright for this article is retained by the author(s), with first publication rights granted to the journal.

This is an open-access article distributed under the terms and conditions of the Creative Commons Attribution license (http://creativecommons.org/licenses/by/3.0/). 